\title{
The HMA-LMA Dichotomy Revisited: an Electron Microscopical Survey of 56 Sponge Species
}

\author{
VOLKER GLOECKNER ${ }^{1}$, MARKUS WEHRL ${ }^{1}$, LUCAS MOITINHO-SILVA ${ }^{1}$, \\ CHRISTINE GERNERT ${ }^{1}$, PETER SCHUPP ${ }^{2}$, JOSEPH R. PAWLIK ${ }^{3}$, NIELS L. LINDQUIST ${ }^{4}$, \\ DIRK ERPENBECK ${ }^{5}$, GERT WÖRHEIDE ${ }^{5,6}$, AND UTE HENTSCHEL ${ }^{1, *}$ \\ ${ }^{1}$ Julius-von-Sachs Institute for Biological Sciences, Department of Botany II, University of Wuerzburg, \\ Julius-von-Sachs Platz 3, 97082 Wuerzburg, Germany; ${ }^{2}$ Carl-von-Ossietzky University Oldenburg, \\ Institute for Chemistry and Biology of the Marine Environment (ICBM), Schleusenstr. 1, 26382 \\ Wilhelmshaven, Germany; ${ }^{3}$ Department of Biology and Marine Biology, Center for Marine Science, \\ University of North Carolina Wilmington, North Carolina, USA; ${ }^{4}$ Institute of Marine Sciences, \\ University of North Carolina at Chapel Hill, North Carolina, USA; ${ }^{5}$ Department of Earth and \\ Environmental Sciences, Palaeontology \& Geobiology, \& GeoBio-Center, Ludwig-Maximilians- \\ Universität München, Richard-Wagner-Str. 10, 80333 München, Germany; and ${ }^{6}$ SNSB-Bayerische \\ Staatssammlung für Paläontologie und Geologie, Richard-Wagner-Str. 10, 80333 München, Germany
}

\begin{abstract}
The dichotomy between high microbial abundance (HMA) and low microbial abundance (LMA) sponges has been long recognized. In the present study, 56 sponge species from three geographic regions (greater Caribbean, Mediterranean, Red Sea) were investigated by transmission electron microscopy for the presence of microorganisms in the mesohyl matrix. Additionally, bacterial enumeration by DAPI-counting was performed on a subset of samples. Of the 56 species investigated, 28 were identified as belonging to the HMA and 28 to the LMA category. The sponge orders Agelasida and Verongida consisted exclusively of HMA species, and the Poecilosclerida were composed only of LMA sponges. Other taxa contained both types of microbial associations (e.g., marine Haplosclerida, Homoscleromorpha, Dictyoceratida), and a clear phylogenetic pattern could not be identified. For a few sponge species, an intermediate microbial load was determined, and the microscopy data did not suffice to reliably determine HMA or LMA status. To experimentally determine the HMA or LMA status of a sponge species, we therefore
\end{abstract}

Received 24 February 2014; accepted 28 May 2014.

The first two authors contributed equally to this work.

* To whom correspondence should be addressed. E-mail: ute. hentschel@uni-wuerzburg.de

Abbreviations: HMA, high microbial abundance; LMA, low microbial abundance. recommend a combination of transmission electron microscopy and 16S rRNA gene sequence data. This study significantly expands previous reports on microbial abundances in sponge tissues and contributes to a better understanding of the HMA-LMA dichotomy in sponge-microbe symbioses.

\section{Introduction}

Sponges (Porifera) represent an evolutionarily ancient phylum with a fossil record dating back to Precambrian times (Li et al., 1998). Today, sponges are important components of the marine benthos and play an important role in the coupling of benthic and pelagic environments owing to their immense filter-feeding capacities (Bell, 2008; de Goeij et al., 2013). Within their mesohyl tissues, many sponges harbor a great diversity of symbiotic microorganisms from the three domains of life: Archaea, Bacteria, and Eukaryota. To date, representatives from more than 28 bacterial phyla (including candidate phyla such as Poribacteria and Tectomicrobia) and two archaeal lineages were identified from marine sponges (Hentschel et al., 2012; Schmitt et al., 2012; Simister et al., 2012). The vast majority of sponge-associated microbes remain uncultivated and are thus functionally largely uncharacterized (Taylor et al., 2007).

The presence of microorganisms in marine sponge tissues has been known for almost a century. Dosse (1939) and 
Levi and Porte (1962) were among the first to describe microorganisms in the sponge mesohyl matrix using transmission electron microscopy. It was soon discovered that while some sponge species harbored dense microbial consortia within their mesohyl tissues, the mesohyl of other species from the same habitat were notably devoid of microorganisms (Reiswig, 1974; Vacelet and Donadey, 1977, Wilkinson, 1978). Accordingly, two general categories were identified that were termed "bacterial sponges" and "non-symbiont harboring, normal sponges" (Reiswig, 1981). Later on, the terms "low microbial abundance" (LMA) and "high microbial abundance" (HMA) sponges were coined to acknowledge the additional presence of archaea in sponge tissues (Hentschel et al., 2003). A typical HMA sponge contains $10^{8}$ to $10^{10}$ microorganisms/g sponge tissue, which can make up to $20 \%-35 \%$ of the sponge biomass (Reiswig, 1981; Webster et al., 2001; Hentschel et al., 2012); in contrast, only $10^{5}$ to $10^{6}$ bacteria/g sponge tissue are found in LMA sponges, which is roughly equivalent to the microbial abundances in seawater (Hentschel et $a l ., 2006)$. This pattern extends to reproductive propagules in that the larvae of HMA sponges contain dense bacterial assemblages at the larval center, while the interior of LMA sponge larvae is largely free of microbes (Ereskovsky and Tokina, 2004; Maldonado, 2007; Schmitt et al., 2007; Gloeckner et al., 2013a, b). Vertical microbial transmission from the parent to the larva, a hallmark of symbiotic hostmicrobe associations (Bright and Bulgheresi, 2010), is now considered an important and presumably evolutionarily ancient component of HMA sponge symbioses. The microbial community is likely complemented by horizontal acquisition of microbes from seawater, although this process has never been demonstrated (Schmitt et al., 2008a; Webster et al., 2010).

Besides bacterial abundances, there are also noticeable differences in microbial diversity between HMA and LMA sponges. Several studies, employing a variety of 16S rRNA gene-based methods, consistently demonstrated a lower microbial diversity in LMA than in HMA sponges (Weisz et al., 2007; Kamke et al., 2010; Erwin et al., 2011; Schmitt et al., 2012; Giles et al., 2013; Gloeckner et al., 2013a; Poppell et al., 2013; Moitinho-Silva et al., 2014). Each LMA species was dominated by a large clade of Proteobacteria (Alpha-, Beta-, or Gamma-) or Cyanobacteria (genus Synechococcus), and there was little overlap between the LMA sponge microbiomes under investigation. The HMA sponge communities, however, showed more phylum-level diversity, with Proteobacteria, Chloroflexi, Acidobacteria, Actinobacteria, candidate phylum Poribacteria, and other phyla as dominant community members. Differences extend also to the microbial physiology of the respective microbial consortia, particularly with respect to nitrogen metabolism (Bayer et al., 2008; Schlappy et al., 2010; Ribes et al., 2012). Distinct differences were further noted regarding the distribution of certain polyketide synthase genes (sup$A P K S$ ) that were found in all HMA but not in the LMA sponges under investigation (Hochmuth et al., 2010). Clearly, much remains to be learned about the metabolism, physiology, and function of sponge-associated microbial consortia, particularly in the context of the HMA or LMA dichotomy.

With respect to animal morphology, Vacelet and Donadey (1977) observed early on that the HMA sponges generally display a denser mesohyl, narrower aquiferous canals, and smaller choanoycte chambers than their LMA counterparts. In other words, the HMA sponges appear to be less well "irrigated." The narrower canals and smaller choanocyte chambers may result in a reduced water flow when compared to LMA sponges (Weisz et al., 2008; Schlappy et al., 2010). In the present study, we revisited the original observations on microbial abundances in sponges; we used electron microscopy complemented by DAPI cell-counting. Altogether, 56 demosponge species from four different geographic locations were investigated. This survey significantly expands previously published datasets on HMA and LMA sponges (Hentschel et al., 2003; Schmitt, 2007; Schmitt et al., 2008a; Weisz et al., 2008), and the findings are interpreted in a taxonomic framework of the animal hosts.

\section{Materials and Methods}

\section{Sponge collection}

Scuba divers from the research vessels R/V Seward Johnson and F. G. Walton Smith, Harbor Branch Oceanographic Institution, Florida, collected sponges from various locations around the Bahamas (termed "BAH") over the years 2003-2013 (Table 1). Sponges were further obtained by scuba diving in 2004 in Key Largo, Florida, USA $\left(25^{\circ} 01^{\prime} \mathrm{N}\right.$, $80^{\circ} 23^{\prime} \mathrm{W}$ ) ("FL"); offshore Rovinj, Croatia $\left(45^{\circ} 08^{\prime} \mathrm{N}\right.$; $13^{\circ} 64^{\prime} \mathrm{E}$ ) ("MED") in 2012; at Souda Bay, Crete, Greece $\left(35^{\circ} 31^{\prime} \mathrm{N}\right.$; $\left.24^{\circ} 09^{\prime} \mathrm{E}\right)$ ("MED") in 2013; and at other Mediterranean locations. Sponge samples were further collected at Fsar reef, Thuwal, Red Sea, Saudi Arabia $\left(22^{\circ} 23^{\prime} \mathrm{N}\right.$; $39^{\circ} 03^{\prime} \mathrm{E}$ ) ("RS") in 2010 (Table 1). Three to five sponge individuals were collected per species and brought to the surface in separate resealable plastic bags. The samples were processed as described below within a few hours after sampling.

\section{Electron microscopy}

Freshly collected sponge material of a few cubic millimeters in size was fixed in $2.5 \%$ glutaraldehyde/phosphatebuffered saline for $12 \mathrm{~h}$, rinsed three times for $20 \mathrm{~min}$ each in PBS, and postfixed in $2 \%$ osmium tetroxide/PBS for $12 \mathrm{~h}$. Several pieces per individual (hereafter termed "technical replicates") were dehydrated in an ethanol series (30\%, $50 \%, 70 \%, 90 \%, 3 \times 100 \%$ ), incubated three times for 20 
Table 1

Sponge collection sites

\begin{tabular}{|c|c|c|}
\hline Location & Collection Site & Sponge Species \\
\hline \multirow[t]{9}{*}{ BAH, Bahamas Islands } & Little San Salvador $24^{\circ} 34.39^{\prime} \mathrm{N} ; 75^{\circ} 58.00^{\prime} \mathrm{W}$ & $\begin{array}{l}\text { Agelas citrina, Agelas dilatata, Aiolochroia crassa, Siphonodictyon } \\
\text { coralliphagum, Iotrochota birotulata, Plakortis sp. }\end{array}$ \\
\hline & San Salvador $24^{\circ} 01.14^{\prime} \mathrm{N} ; 7^{\circ} 32.68^{\prime} \mathrm{W}$ & $\begin{array}{l}\text { Agelas dispar, Aplysina cauliformis var. thick, Aplysina insularis, } \\
\text { Verongula gigantea, Ptilocaulis sp., Cliona varians }\end{array}$ \\
\hline & Sweetings Cay $26^{\circ} 36.0^{\prime} \mathrm{N} ; 77^{\circ} 52.60^{\prime} \mathrm{W}$ & Cribrochalina vasculum, Dysidea etheria \\
\hline & Chub Cay $25^{\circ} 23.365^{\prime} \mathrm{N} ; 7^{\circ} 52.127^{\prime} \mathrm{W}$ & Aplysina cauliformis var. thin, Monanchora arbuscula \\
\hline & $\begin{array}{l}\text { Grand Bahama Island } 25^{\circ} 1.282^{\prime} \mathrm{N} \\
77^{\circ} 34.56^{\prime} \mathrm{W}\end{array}$ & Aplysina archeri, Aplysina fistularis, Chalinula molitba \\
\hline & Exuma Cay $24^{\circ} 25.642^{\prime} \mathrm{N} ; 76^{\circ} 40.464^{\prime} \mathrm{W}$ & $\begin{array}{l}\text { Myrmekioderma gyroderma, Spheciospongia vesparium, Erylus } \\
\text { formosus }\end{array}$ \\
\hline & Bimini $25^{\circ} 45.316^{\prime} \mathrm{N} ; 79^{\circ} 18.061^{\prime} \mathrm{W}$ & Batzella rubra, Cinachyrella alloclada \\
\hline & Great Inagua $21^{\circ} 05.945^{\prime} \mathrm{N} ; 73^{\circ} 40.216^{\prime} \mathrm{W}$ & Plakortis lita, Svenzea zeai \\
\hline & Cat Cay $25^{\circ} 31.480^{\prime} \mathrm{N} ; 79^{\circ} 17.938^{\prime} \mathrm{W}$ & Callyspongia plicifera \\
\hline \multirow[t]{4}{*}{ MED, Mediterranean } & Rovinj, Croatia $45^{\circ} 05^{\prime} \mathrm{N}, 13^{\circ} 38^{\prime} \mathrm{E}$ & $\begin{array}{l}\text { Aplysina aerophoba, Chondrosia reniformis, Axinella polypoides, } \\
\text { Tethya aurantium, Suberites domuncula, Dysidea avara }\end{array}$ \\
\hline & $\begin{array}{l}\text { Marseille, France } 43^{\circ} 11^{\prime} 48.92^{\prime} \mathrm{N} \\
5^{\circ} 21^{\prime} 48.62^{\prime} \mathrm{E}\end{array}$ & Aplysina cavernicola, Oscarella lobularis \\
\hline & Banyuls-sur-Mer, France $42^{\circ} 29^{\prime} \mathrm{N} ; 03^{\circ} 08^{\prime} \mathrm{E}$ & Crambe crambe \\
\hline & $\begin{array}{l}\text { Souda, Crete, Greece } 36^{\circ} 76.759^{\prime} \mathrm{N} \\
\quad 24^{\circ} 51.422^{\prime} \mathrm{E}\end{array}$ & Petrosia sp., Acanthella acuta, Axinella cannabina \\
\hline FL, Florida & Key Largo, USA $24^{\circ} 56.863^{\prime} \mathrm{N} ; 80^{\circ} 27.230^{\prime} \mathrm{W}$ & $\begin{array}{l}\text { Agelas wiedenmayeri, Xestospongia muta, Ircinia felix, Ircinia } \\
\text { strobilina, Smenospongia aurea, Ecytoplasia ferox, Scopalina } \\
\text { ruetzleri, Tedania ignis, Mycale laxissima, Niphates erecta, } \\
\text { Niphates digitalis, Amphimedon compressa, Callyspongia } \\
\text { vaginalis, Aplysina lacunosa }\end{array}$ \\
\hline Red Sea & $\begin{array}{l}\text { Fsar Reef, Jeddah, Saudi Arabia } 22^{\circ} 23.096^{\prime} \mathrm{N} \text {; } \\
\quad 39^{\circ} 02.856^{\prime} \mathrm{E}\end{array}$ & $\begin{array}{l}\text { Amphimedon ochracea, Crella cyathophora, Stylissa carteri, } \\
\text { Xestospongia testudinaria }\end{array}$ \\
\hline
\end{tabular}

min each in propylene oxide and polymerized in Epon 812 (Serva, Germany) for 4 days at $60{ }^{\circ} \mathrm{C}$. The embedded sponge pieces were sectioned with an ultramicrotom (OM U3, C. Reichert, Austria). For contrasting, 70-80-nm thick sections were post-stained with $0.5 \%$ uranyl acetate in methanol for $10 \mathrm{~min}$ and Reynolds lead citrate for $5 \mathrm{~min}$. The resulting sections were investigated by electron microscopy (Zeiss EM 10, Zeiss, Germany). Several different images of three biological specimens were inspected for each species.

\section{Bacterial quantification protocol}

A piece of sponge tissue of about $1 \mathrm{~g}$ was removed with an ethanol-sterilized scalpel blade and rinsed three times with $0.2-\mu \mathrm{m}$ filter-sterilized seawater. The tissue cube was cut so that one side always represented the surface tissue. A $10 \times$ dilution was obtained by adding $1 \mathrm{ml}$ of sponge tissue to $9 \mathrm{ml}$ of $0.2-\mu \mathrm{m}$ filter-sterilized seawater. The tissue was homogenized with a mortar and pestle and poured through Nitex (100- $\mu \mathrm{m}$ pore size) to remove unground tissue pieces. The suspension was fixed in paraformaldehyde to a final concentration of $3.7 \%$ and stored at $4{ }^{\circ} \mathrm{C}$ until use. The tissue remainders were rinsed off the Nitex sheet with 0.5 -ml filter-sterilized seawater and homogenized, using a mortar and pestle, in $4.5 \mathrm{ml}$ of filter-sterilized seawater. The suspension was poured through Nitex, fixed in $3.7 \%$ paraformaldehyde final concentration, and stored at $4{ }^{\circ} \mathrm{C}$ until use. Dilutions ranging from $10^{-1}$ to $10^{-3}$ were prepared from each homogenate. One milliliter of each dilution was stained with $0.7 \mu \mathrm{g} / \mathrm{ml}$ DAPI (4,6-Diamidino-2-phenylindole) final concentration in the dark for $30 \mathrm{~min}$. The DAPI stock solution $\left(100 \mu \mathrm{g} \mathrm{ml}^{-1}\right)$ was prepared weekly and stored at $4{ }^{\circ} \mathrm{C}$. A volume of $1 \mathrm{ml}$ of stained homogenate was added to $9 \mathrm{ml}$ of filter-sterilized seawater and filtered onto a black, $0.2-\mu \mathrm{m}$ polycarbonate membrane $25 \mathrm{~mm}$ in diameter (Millipore, Germany) that was supported by an $0.45-\mu \mathrm{m}$ cellulose nitrate filter (Schleicher und Schuell, Germany). Vacuum $(<10 \mathrm{~cm} \mathrm{Hg})$ was applied carefully with a hand pump. The filters were washed once with filter-sterilized seawater and subsequently rinsed with $3 \mathrm{ml}$ of $70 \%$ ethanol. The $0.2-\mu \mathrm{m}$ polycarbonate filter was then mounted with Citifluor (Citifluor Ltd., UK) onto a microscope slide. Bacterial numbers were determined after epifluorescence microscopy using a $100 \times$ magnification oil lense (Axiolab microscope, Zeiss, Germany). Three independent specimens were processed for each species. Each sample represents an average bacterial number from 10 different counting fields. For each sample, the numbers of bacteria and 

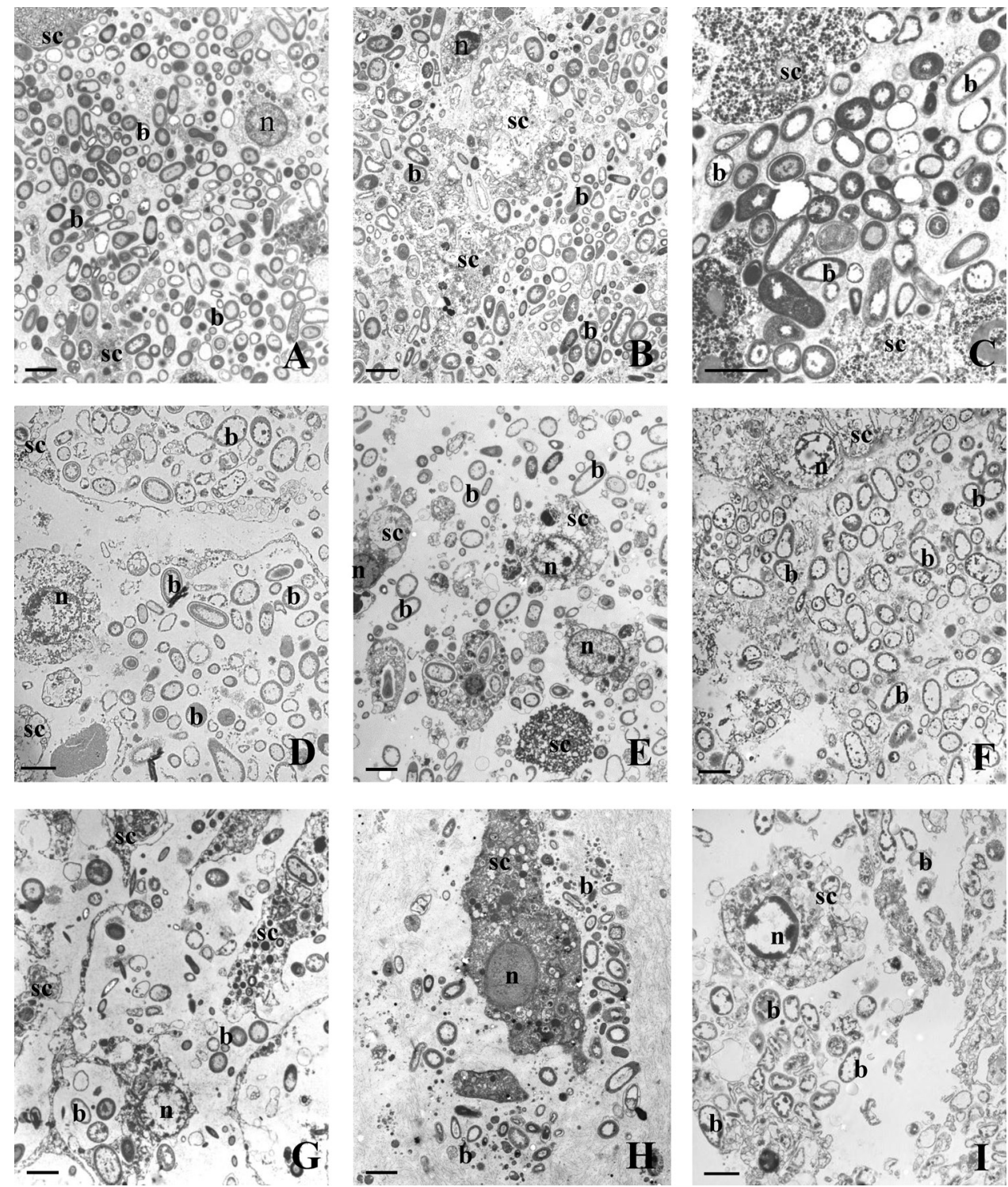

Figure 1. Transmission electron microscopy of selected high microbial abundance sponge species. $\mathrm{A}=$ Aplysina aerophoba, $\mathrm{B}=$ Spheciospongia vesparium, $\mathrm{C}=$ Aiolochroia crassa, $\mathrm{D}=$ Petrosia $\mathrm{sp} ., \mathrm{E}=$ Xestospongia testudinaria, $\mathrm{F}=$ Plakortis lita, $\mathrm{G}=$ Agelas dispar, $\mathrm{H}=$ Ircinia felix, $\mathrm{I}=$ Svenzea zeai . Scale bar, $2 \mu \mathrm{m}$; b, bacteria; $\mathrm{n}$, nucleus; sc, sponge cell.

nuclei were counted, and the results from the first and second homogenate were summed. The number of cyanobacteria was counted using the red and green fluorescent filter set.

\section{S rRNA sponge phylogeny}

Nearly full-length $18 \mathrm{~S}$ rRNA gene sequences published in NCBI GenBank (http://www.ncbi.nlm.nih.gov) were analyzed. In a few cases, the 18S rRNA gene sequences were unavailable and the sequence of a closely related congeneric (and in the case of Batzella rubra, of a confamiliar sequence) were therefore substituted, taking the current changes in demosponge classification into consideration (Redmond et al., 2013). Altogether 45 sponge species were included in the phylogenetic tree, and the GenBank accession numbers are provided in Figure 3. The sequences were aligned using the Sponge Genetree Server with 18S rRNA gene secondary structure information included in the analysis (Erpenbeck et al., 2008). Positions that could not be aligned were excluded from further analyses. Maximumlikelihood reconstruction was inferred with RAxML 7.2.5 (Stamatakis, 2006) using the GTRGAMMI model of nucleotide substitution as suggested by jModeltest ver. 0.1.1. (Darriba et al., 2012) under the Akaike Information 

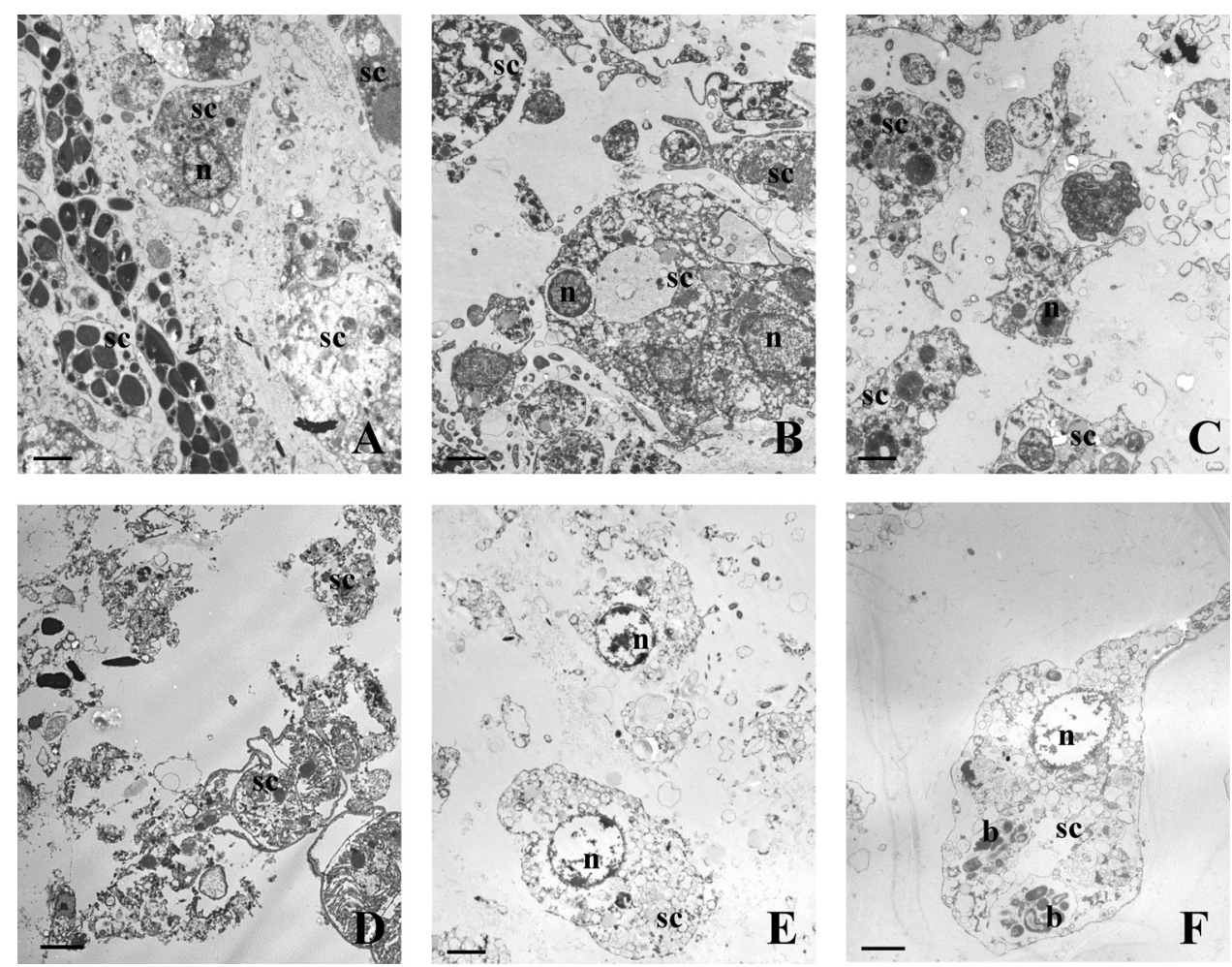

Figure 2. Transmission electron microscopy of selected low microbial abundance sponges. A $=$ Erylus formosus, $\mathrm{B}=$ Monanchora arbuscula, $\mathrm{C}=$ Scopalina ruetzleri, $\mathrm{D}=$ Amphimedon ochracea, $\mathrm{E}=$ Axinella cannabina, F = Acanthella acuta. Scale bar, $2 \mu \mathrm{m}$; b, bacteria; n, nucleus; sc, sponge cell.

Criterion (Akaike, 1974) and 100 fast bootstrap replicates. Analyses were performed on the 64-node Linux cluster of the Molecular Geo- and Palaeobiology Labs, Ludwig Maximilian University, Munich.

\section{Results and Discussion}

In the present study, 56 sponge species were inspected by transmission electron microscopy (TEM) for the presence of microorganisms in the mesohyl matrix. Of the 41 sponge species examined from the greater Caribbean (Bahamas and Florida locations, Table 1), 24 were identified as high microbial abundance (HMA) and 17 as low microbial abundance (LMA) (Tables 2, 3). Of the 12 species sampled from the various Mediterranean locations, four were identified as HMA and eight as LMA. From the Red Sea collection site, one sponge was identified as HMA and three as LMA. For previous TEM-based surveys of HMA and LMA sponge patterns, the reader is referred to the literature: Hentschel $e t$ al. (2003) and references cited therein; Schmitt et al. (2008b); Weisz et al. (2008); Popell et al. (2013). The question arises whether the sponges fall into strict HMA or LMA categories or whether they rather represent a continuum. Judging from our data, the HMA-LMA dichotomy may be best described as a continuum with a highly biomodal distribution, in the sense that most investigated species are found at the extreme ends (either HMA or LMA) of the continuum.

The HMA sponge tissues contained dense and morphologically diverse microorganisms that are located largely extracellularly in the mesohyl matrix (Fig. 1A-I). In extreme cases, the microbial cells are much more abundant than sponge cells, as shown here for Aplysina aerophoba (Fig. 1A) and Spheciospongia vesparium (Fig. 1B) as well as elsewhere, for example, for the order Verongida (Vacelet, 1975; Friedrich et al., 1999). Our data support the results of Weisz et al. (2008) but disagree with those of Popell et al. (2013) in that $S$. vesparium is classified here as an HMA sponge. While the potential for phenotypic plasticity in microbial amount cannot be ruled out, we have found microbial abundance to be a highly conserved trait on the level of sponge species.

In general, there is a remarkably stable presence of certain bacterial morphotypes, of which some appear to contain intracellular compartments and unusual membrane structures (Fig. 1C). Some of these originally described morphotypes (i.e., types A and C according to Vacelet, 1975, and Friedrich et al., 1999) can readily be identified in the present pictures of HMA sponge tissue. The amount of bacteria in the HMA sponge tissues can, however, be variable, ranging from densely packed mesohyl tissues for the order 
Table 2

A compilation of high microbial abundance (HMA) sponge species

\begin{tabular}{|c|c|c|c|}
\hline Species & $\begin{array}{l}\text { Collection } \\
\text { Site* }\end{array}$ & $\begin{array}{c}\text { Transmission Electron Microscopy } \\
\text { Reference } \uparrow\end{array}$ & Higher Taxon§ \\
\hline Agelas citrina & $\mathrm{BAH}$ & Wehrl 2006 & Agelasida \\
\hline Agelas dilatata & $\mathrm{BAH}$ & Wehrl 2006 & Agelasida \\
\hline Agelas dispar & $\mathrm{BAH}$ & This study & Agelasida \\
\hline Agelas wiedenmayeri & FL & Wehrl 2006; Schmitt et al. 2008b & Agelasida \\
\hline Aiolochroia crassa & $\mathrm{BAH}$ & This study & Verongida \\
\hline Aplysina aerophoba & MED & Hentschel et al. 2003; Siegl et al. 2008 & Verongida \\
\hline Aplysina archeri & $\mathrm{BAH}$ & Wehrl 2006 & Verongida \\
\hline Aplysina cauliformis, thick morphotype & $\mathrm{BAH}$ & Wehrl 2006 & Verongida \\
\hline Aplysina cauliformis, thin morphotype & BAH & Wehrl 2006 & Verongida \\
\hline Aplysina cavernicola & MED & Wehrl 2006; Friedrich et al. 1999, 2001 & Verongida \\
\hline Aplysina fistularis & BAH & Wehrl 2006; Gloeckner 2013 & Verongida \\
\hline Aplysina insularis & $\mathrm{BAH}$ & Wehrl 2006 & Verongida \\
\hline Aplysina lacunosa & FL & Wehrl 2006 & Verongida \\
\hline Chondrosia reniformis & MED & Wehrl 2006 & Chondrosida \\
\hline Cribrochalina vasculum & $\mathrm{BAH}$ & Schiller 2006 & (marine) Haplosclerida \\
\hline Ectyoplasia ferox & FL & Schmitt et al. 2008a,b; Gloeckner et al. 2013 & Raspailiidae \\
\hline Ircinia felix & FL & Schmitt et al. 2007 & Dictyoceratida \\
\hline Ircinia strobilina & FL & Schmitt 2007 & Dictyoceratida \\
\hline Myrmekioderma gyroderma & BAH & Gloeckner 2013 & "Halichondrida" \\
\hline Petrosia sp. & MED & This study & (marine) Haplosclerida \\
\hline Plakortis lita & BAH & This study & Homoscleromorpha \\
\hline Plakortis sp. & BAH & Laroche et al. 2007 & Homoscleromorpha \\
\hline Siphonodictyon coralliphagum & BAH & Schiller 2006; Schmitt et al. 2008b & (marine) Haplosclerida \\
\hline Smenospongia aurea & FL & Schmitt et al., 2008b; Gloeckner 2013 & Dicytoceratida \\
\hline Spheciospongia vesparium & $\mathrm{BAH}$ & This study & "Hadromerida" \\
\hline Svenzea zeai & $\mathrm{BAH}$ & This study & "Halichondrida" \\
\hline Verongula gigantea & BAH & Wehrl 2006 & Verongida \\
\hline Xestospongia muta & FL & Wehrl 2006; Hentschel et al. 2006 & (marine) Haplosclerida \\
\hline Xestospongia testudinaria & RS & This study & (marine) Haplosclerida \\
\hline
\end{tabular}

* BAH, Bahama Islands; FL, Florida; MED, Mediterranean; RS, Red Sea.

$\dagger$ Some transmission electron microscopy data were reported in Master's (Schiller, 2006) and Ph.D. theses (Wehrl, 2006; Schmitt, 2007; Gloeckner, 2013).

$\S$ Higher taxon names in quotation marks indicate orders recognized as non-monophyletic which may be subject to emendings in the future.

Verongida (Fig. 1A) to moderately dense microbial consortia such as those of the taxa Ircinia or Agelas (Fig. 1G, H). However, additional literature reports based on $16 \mathrm{~S}$ rRNA gene sequencing and inspections of microbial abundances in larval tissues clearly identified these species as HMA sponges (Schmitt et al., 2007, 2008a,b; Schmitt, 2007). Experimental artefacts may have arisen for sponges that were difficult to cut with a diving knife (i.e., Ircinia), or for sponges having tissues that are less cohesive (i.e., Xestospongia). However, the consistency between technical replicates (representing samples from the same individual) and between biological replicates (representing samples from different individuals) is remarkably high in our experience.

Relative to HMA sponge species, the mesohyl of LMA sponges was noticeably devoid of microorganisms (Fig. 2). A few intracellular bacteria in various stages of digestion were present that likely represent food bacteria (Fig. 2F). Occasionally, bacterial morphotypes were observed in TEM pictures of LMA sponges (Gloeckner et al., 2013a); how- ever, the morphotype diversity appeared unlike that of HMA sponges in that the compartmentalized cells and those with unusual membranes were missing (Vacelet, 1975; Friedrich et al., 1999). Therefore, on the basis of electron microscopical observations, the combination of bacterial abundance and morphotype diversity determines whether a sponge species belongs to the HMA or LMA category. However, in some sponges with intermediate bacterial abundances, TEM may not be sufficient to determine whether a given species is HMA or LMA, and in these exceptional cases, additional methods are needed.

When the status of a sponge species as either HMA or LMA was equivocal on the basis of microscopical observations, an independent line of evidence was sought in microbial enumeration by staining with DAPI (Table 4). Sponge tissue homogenates were used for bacterial and cyanobacterial quantification, and numbers were either expressed in total or as ratios relative to the number of sponge nuclei. Further, sponge homogenates were screened for the 
Table 3

A compilation of low microbial abundance (LMA) sponge species

\begin{tabular}{|c|c|c|c|}
\hline Species & $\begin{array}{l}\text { Collection } \\
\text { Site* }\end{array}$ & $\begin{array}{c}\text { Transmission Electron Microscopy } \\
\text { Reference } \dagger\end{array}$ & Higher Taxon§ \\
\hline Acanthella acuta & MED & This study & "Halichondrida" \\
\hline Amphimedon compressa & $\mathrm{FL}$ & Angermeier et al. 2012 & (marine) Haplosclerida \\
\hline Amphimedon ochracea & $\mathrm{RS}$ & This study & (marine) Haplosclerida \\
\hline Axinella cannabina & MED & This study & "Halichondrida" \\
\hline Axinella polypoides & MED & Wehrl 2006 & "Halichondrida" \\
\hline Batzella rubra & BAH & Gloeckner 2013 & Poecilosclerida (s.s.) \\
\hline Callyspongia plicifera & BAH & Gloeckner 2013 & (marine) Haplosclerida \\
\hline Callyspongia vaginalis & FL & Schiller 2006; Wehrl 2006 & (marine) Haplosclerida \\
\hline Chalinula molitba & BAH & Schiller 2006; Wehrl 2006 & (marine) Haplosclerida \\
\hline Cinachyrella alloclada & BAH & Gloeckner 2013 & Spirophorida \\
\hline Cliona varians & BAH & Schiller 2006 & "Hadromerida" \\
\hline Crambe crambe & MED & Wehrl 2006 & Poecilosclerida (s.s.) \\
\hline Crella cyathophora & RS & Giles et al. 2012 & Poecilosclerida (s.s.) \\
\hline Dysidea avara & MED & Wehrl 2006 & Dictyoceratida \\
\hline Dysidea etheria & BAH & Schiller 2006 & Dictyoceratida \\
\hline Erylus formosus & BAH & This study & Astrophorida \\
\hline Iotrochota birotulata & BAH & Wehrl 2006 & Poecilosclerida (s.s.) \\
\hline Monanchora arbuscula & BAH & This study & Poecilosclerida (s.s.) \\
\hline Mycale laxissima & $\mathrm{FL}$ & Wehrl 2006 & Poecilosclerida (s.s.) \\
\hline Niphates digitalis & FL & Schiller 2006; Wehrl 2006 & (marine) Haplosclerida \\
\hline Niphates erecta & FL & Wehrl 2006 & (marine) Haplosclerida \\
\hline Oscarella lobularis & MED & Gloeckner et al. 2013 & Homoscleromorpha \\
\hline Ptilocaulis sp. & $\mathrm{BAH}$ & Wehrl 2006 & "Halichondrida" \\
\hline Scopalina ruetzleri & $\mathrm{FL}$ & Wehrl 2006; Gloeckner 2013 & "Halichondrida" \\
\hline Stylissa carteri & RS & Giles et al. 2013 & "Halichondrida" \\
\hline Suberites domuncula & MED & Wehrl 2006 & "Hadromerida" \\
\hline Tedania ignis & $\mathrm{FL}$ & Schiller 2006; Wehrl 2006 & Poecilosclerida (s.s.) \\
\hline Tethya aurantium & MED & Wehrl 2006 & "Hadromerida" \\
\hline
\end{tabular}

* BAH, Bahama Islands; FL, Florida; MED, Mediterranean; RS, Red Sea.

$†$ Some transmission electron micrography data were reported in Master's (Schiller 2006) and PhD theses (Wehrl 2006; Schmitt 2007; Gloeckner 2013).

$\S$ Higher taxon names in quotation marks indicate orders recognized as non-monophyletic and may be subject to emendings in the future.

presence or absence of bacteria, using defined HMA and LMA sponge homogenates as controls. The sponge species subjected to this analysis formed two distinct groups of HMA and LMA sponges, which mirrored the TEM observations. Siphonodictyon coralliphagum was the only exception, in which the low bacterial numbers obtained by DAPI staining indicated it was an LMA sponge, but the TEM observations identified it as an HMA sponge (Schmitt, 2007). The DAPI method can be prone to errors; for example, if the bacterial cells are disrupted upon tissue homogenization, particularly as a result of the presence of cytotoxic secondary metabolites. However, this problem happened only once in 56 species investigated and appeared to be a rare scenario. The ratio of bacteria per sponge cell nuclei was variable, ranging from 17 to 95 bacterial cells per sponge cell nucleus for Xestospongia muta and Agelas insularis, respectively, and from 0 to 5 bacterial cells per sponge cell nucleus for the LMA sponges (Table 4). These data support the TEM observations that HMA sponges contain variable amounts of microorganisms in the mesohyl tissues. Major disadvantages of the DAPI-staining method were the large amount of background staining and the limited applicability to sponges with high intrinsic autofluorescence. Also, some sponge tissues were difficult to macerate and yielded clumpy homogenates, making it difficult to determine precise numbers. In these cases, confocal microscopy on sponge tissue sections, as recently employed by Ribes and coworkers (Ribes et al., 2012), is a suitable alternative for microbial visualization and quantification in sponge tissues.

Several recent publications addressed the HMA-LMA dichotomy by $16 \mathrm{~S}$ rRNA gene sequencing. Whether obtained by clone libraries (Kamke et al., 2010; Giles et al., 2013), DGGE (Weisz et al., 2007; Gloeckner et al., 2013a; Poppell et al., 2013,), terminal restriction fragment length polymorphism (T-RFLP) (Erwin et al., 2011), or amplicon sequencing (Schmitt et al., 2012; Moitinho-Silva et al., 2014), the data consistently revealed a different bacterial composition in LMA sponges than in HMA sponges. Similarly, in comparative DGGEs, the LMA sponges 
Table 4

Quantification of bacteria, cyanobacteria, and sponge nuclei by DAPI staining (per ml sponge homogenate)

\begin{tabular}{|c|c|c|c|c|c|}
\hline Species & Bacteria Mean \pm SE & $\begin{array}{c}\text { Cyanobacteria } \\
\text { Mean } \pm \text { SE }\end{array}$ & $\begin{array}{c}\text { Bacteria Total } \\
\text { Mean } \pm \text { SE }\end{array}$ & Nuclei Mean \pm SE & Ratio* \\
\hline \multicolumn{6}{|l|}{$\begin{array}{l}\text { High microbial abundance } \\
\text { sponges } \dagger\end{array}$} \\
\hline Agelas citrina & $7.0 \times 10^{8} \pm 2.1 \times 10^{8}$ & $2.6 \times 10^{6} \pm 2.0 \times 10^{6}$ & $7.0 \times 10^{8} \pm 2.1 \times 10^{8}$ & $3.2 \times 10^{7} \pm 5.7 \times 10^{6}$ & 22.16 \\
\hline A. dilatata & $1.9 \times 10^{9} \pm 8.7 \times 10^{8}$ & $1.5 \times 10^{6} \pm 9.6 \times 10^{5}$ & $1.9 \times 10^{9} \pm 8.7 \times 10^{8}$ & $5.7 \times 10^{7} \pm 1.7 \times 10^{7}$ & 33.40 \\
\hline Aplysina archeri & $1.4 \times 10^{9} \pm 1.9 \times 10^{7}$ & $1.1 \times 10^{7} \pm 5.8 \times 10^{6}$ & $1.4 \times 10^{9} \pm 2.4 \times 10^{7}$ & $3.5 \times 10^{7} \pm 1.8 \times 10^{7}$ & 39.16 \\
\hline A. insularis & $6.2 \times 10^{9} \pm 4.2 \times 10^{8}$ & $2.9 \times 10^{8} \pm 7.3 \times 10^{7}$ & $6.5 \times 10^{9} \pm 4.9 \times 10^{8}$ & $6.8 \times 10^{7} \pm 2.2 \times 10^{6}$ & 95.71 \\
\hline Cribochalina vasculum & $5.5 \times 10^{9} \pm 2.3 \times 10^{9}$ & $1.1 \times 10^{9} \pm 1.7 \times 10^{7}$ & $6.6 \times 10^{9} \pm 2.4 \times 10^{7}$ & $2.1 \times 10^{8} \pm 3.3 \times 10^{7}$ & 31.71 \\
\hline Xestospongia muta & $7.0 \times 10^{9} \pm 5.5 \times 10^{8}$ & $1.2 \times 10^{9} \pm 2.8 \times 10^{8}$ & $8.2 \times 10^{9} \pm 7.7 \times 10^{8}$ & $4.8 \times 10^{8} \pm 4.1 \times 10^{7}$ & 16.96 \\
\hline Ircinia felix & $1.0 \times 10^{9} \pm 7.3 \times 10^{7}$ & $5.7 \times 10^{8} \pm 7.1 \times 10^{6}$ & $1.6 \times 10^{9} \pm 7.4 \times 10^{7}$ & $6.1 \times 10^{7} \pm 1.2 \times 10^{7}$ & 25.67 \\
\hline Plakortis sp. & $4.3 \times 10^{9} \pm 8.0 \times 10^{8}$ & $3.6 \times 10^{7} \pm 1.6 \times 10^{7}$ & $4.3 \times 10^{9} \pm 7.9 \times 10^{8}$ & $4.8 \times 10^{7} \pm 1.6 \times 10^{7}$ & 89.23 \\
\hline Ecytoplasia ferox & $8.7 \times 10^{9} \pm 1.7 \times 10^{8}$ & n.d. & $8.7 \times 10^{9} \pm 1.7 \times 10^{8}$ & $3.8 \times 10^{8} \pm 2.6 \times 10^{7}$ & 22.94 \\
\hline \multicolumn{6}{|l|}{$\begin{array}{l}\text { Low microbial abundance } \\
\text { spongesđ }\end{array}$} \\
\hline Iotrochota birotulata & $2.4 \times 10^{9} \pm 2.8 \times 10^{8}$ & n.d. & $2.4 \times 10^{9} \pm 2.8 \times 10^{8}$ & $5.2 \times 10^{8} \pm 4.3 \times 10^{7}$ & 4.67 \\
\hline $\begin{array}{l}\text { Siphonodictyon } \\
\text { coralliphagum }\end{array}$ & $2.0 \times 10^{8} \pm 1.5 \times 10^{7}$ & n.d. & $2.0 \times 10^{8} \pm 1.5 \times 10^{7}$ & $2.2 \times 10^{8} \pm 6.2 \times 10^{7}$ & 0.93 \\
\hline Dictyonella funicularis & n.d. & n.d. & n.d. & $3.2 \times 10^{8} \pm 1.4 \times 10^{7}$ & 0.00 \\
\hline Tedania ignis & n.d. & n.d. & n.d. & $8.9 \times 10^{8} \pm 5.2 \times 10^{7}$ & 0.00 \\
\hline Chalinula molitba & $3.5 \times 10^{6} \pm 3.5 \times 10^{6}$ & n.d. & $3.5 \times 10^{6} \pm 3.5 \times 10^{6}$ & $6.1 \times 10^{8} \pm 7.4 \times 10^{7}$ & 0.01 \\
\hline Niphates digitalis & n.d. & n.d. & n.d. & $4.6 \times 10^{8} \pm 1.3 \times 10^{8}$ & 0.00 \\
\hline Amphimedon compressa & n.d. & n.d. & n.d. & $1.4 \times 10^{8} \pm 2.3 \times 10^{7}$ & 0.00 \\
\hline Callyspongia vaginalis & $2.2 \times 10^{6} \pm 1.6 \times 10^{6}$ & $1.8 \times 10^{6} \pm 1.8 \times 10^{6}$ & $4.0 \times 10^{6} \pm 2.0 \times 10^{6}$ & $5.5 \times 10^{8} \pm 1.1 \times 10^{7}$ & 0.01 \\
\hline Ptilocaulis sp. & n.d. & n.d. & n.d. & $3.7 \times 10^{8} \pm 3.2 \times 10^{7}$ & 0.00 \\
\hline Cliona varians & n.d. & n.d. & n.d. & $2.0 \times 10^{8} \pm 2.1 \times 10^{7}$ & 0.00 \\
\hline Dysidea etheria & $3.1 \times 10^{6} \pm 1.2 \times 10^{6}$ & $1.3 \times 10^{6} \pm 7.6 \times 10^{5}$ & $4.4 \times 10^{6} \pm 1.9 \times 10^{6}$ & $1.9 \times 10^{8} \pm 8.1 \times 10^{6}$ & 0.02 \\
\hline Caribbean seawater & & & $3.5 \times 10^{5} \pm 5.7 \times 10^{4}$ & & \\
\hline
\end{tabular}

* Ratio of total bacteria/nuclei.

$\dagger$ The following additional sponges were identified as HMA by qualitative DAPI screening: Ectyoplasia ferox, Myrmekioderma gyroderma, Agelas dispar, Ircinia felix, Ircinia strobilina, Smenospongia aurea, Aplysina cauliformis, Aplysina fistularis, Verongula gigantea, Aiolochroia crassa, Geodia neptuni, Chondrosia collectrix, Calyx podatypa.

If The following additional sponges were identified as LMA by qualitative DAPI screening: Erylus formosus, Mycale (Arenochalina) laxissima, Batzella rubra, Monanchora arbuscula, Scopalina ruetzleri, Callyspongia plicifera, Callyspongia vaginalis, Cinachyrella alloclada.

$\S$ For Siphonodictyon coralliphagum, the low bacterial bacterial numbers determined by DAPI staining contradict its status as an HMA sponge, as determined by transmission electron microscopy (Schmitt et al., 2008b).

n.d. $=$ not detected.

consistently displayed less complex banding patterns than their HMA counterparts (Weisz et al., 2007; Gerce et al., 2011; Poppell et al., 2013). Even small 16S rRNA gene clone libraries were sufficient to detect the major phylogenetic lineages (Moitinho-Silva and Hentschel, unpubl. data). 16S rRNA gene data have therefore proven to be very useful to infer the HMA or LMA status of the host sponge.

The host phylogeny based on nearly full-length $18 \mathrm{~S}$ rRNA gene sequences corroborates the current molecular phylogenetic hypotheses of demosponges (e.g., Morrow et al., 2012; see also Redmond et al. (2013) for the most comprehensive 18S rRNA gene phylogeny). However, as the new nomenclature is yet to be finalized, we refer to taxon names as currently used in the World Porifera Database (van Soest et al., 2014). Several clades were recovered that in the present sample set consisted exclusively of HMA taxa (Verongida, Agelasida (Agelas)), while the Poecilo- sclerida (sensu stricto) clade with representatives from six families consisted exclusively of LMA species (Fig. 3). For the remaining clades, of which many orders and families are currently under redefinition (see, e.g., Redmond et al., 2013), distinct HMA/LMA distribution patterns were not recognized. Additional and distinct patterns might be revealed on lower taxonomic levels given a more representative taxonomic sampling. It is noteworthy, however, that the HMA/LMA characteristics are conserved in closely related species over time and space when collected from different geographic regions (Wilkinson, 1978; Montalvo and Hill, 2011).

The question remains open as to what causes the HMALMA dichotomy. A survey of the literature revealed no apparent correlation with host defense status (Chanas and Pawlik, 1995; Pawlik et al., 1995), with reproductive mode (oviparous vs. viviparous), or with ecological parameters, as 


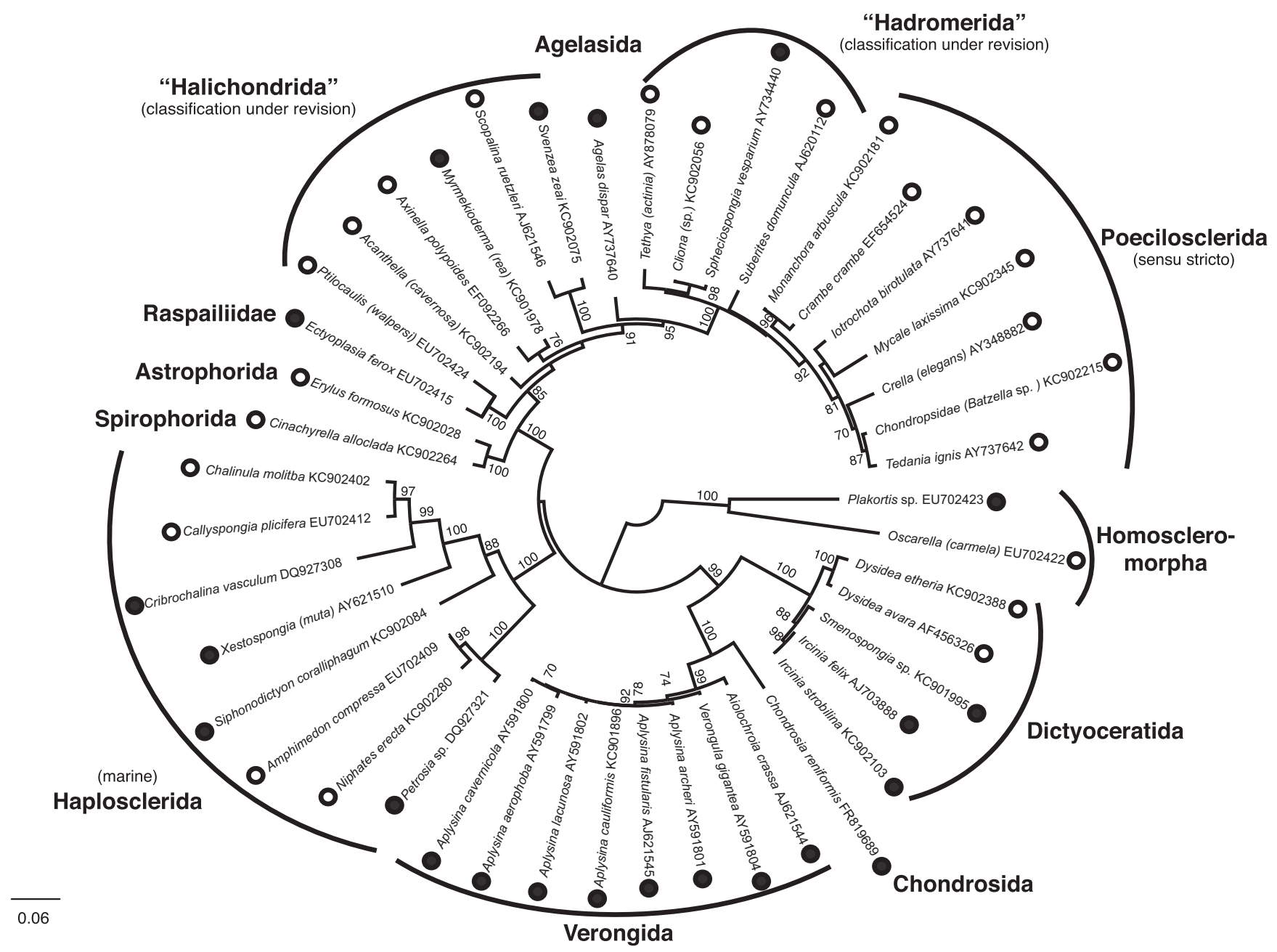

Figure 3. Maximum-likelihood reconstruction of the sponge hosts using almost complete 18S rRNA gene sequences as a phylogenetic marker. Taxon names in parentheses describe the closest related taxon that was used when the 18S rRNA gene sequence of a given host species was unavailable. Numbers at the branches are bootstrap probabilities $>70 \%$. The taxon names are followed by the NCBI GenBank accession numbers. Black filled dots depict high microbial abundance sponges; unfilled dots, low microbial abundance sponges. Scale bar, substitutions/site.

both types of sponges coexist in the same habitat (Schiller, 2006). A phylogenetic signature is present only to a moderate extent. At this point it appears most likely that sponge morphology is an important determining factor. The HMA sponges are frequently large and massive and generally have a firm touch and fleshy consistency, while LMA sponges are generally smaller and feel fragile, soft, brittle, or tough (U.H., pers. obs.). Similarly, the architecture of the sponge interior plays a determining role (Vacelet and Donadey, 1977; Weisz et al., 2008). A higher choanocyte chamber density in LMA sponges was reported by Poppell (2013) and Schlappy (2010). A current hypothesis states that LMA sponges invest more energy into feeding structures, whereas the nutrition of HMA sponges is supplemented by their microbial symbionts (Poppell et al., 2013). With respect to the postulated role of symbionts in the "sponge loop" (de
Goeij et al., 2013), an improved understanding of the different feeding strategies of the sponge "holobiont" is clearly a worthwhile undertaking. It is further safe to speculate that HMA sponges are morphologically adapted to house microbial consortia within their tissues. In evolutionary terms, the question arises whether the sponges are preconditioned to host microbes or whether the animal tissue morphology is a consequence of it containing the microbes. If preconditioned, it is conceivable that the extracellular matrix (ECM) of HMA sponges may be structurally altered to accommodate the presence of sponge symbionts; and vice versa, that the sponge symbionts may have mechanisms to survive within ECM, modifying it with their activities. Indeed, a recent study provides compelling evidence obtained by single-cell genomics that poribacterial sponge symbionts can degrade ECM for nutritional purposes (Kamke et al., 2013). 
Although the present study is the most comprehensive survey for HMA and LMA patterns to date, more investigations are needed with greater taxonomic depth, including analysis of specimens from other sponge classes besides Demospongiae; and including more locations, such as the Great Barrier Reef, the deep-sea, and the polar seas. With regard to methodologies, we propose a combination of transmission electron microscopy and 16S rRNA gene sequence data to reliably determine the HMA or LMA status of the host sponge. The latter is particularly recommended when TEM data yield ambiguous results. The present sponge survey will help pave the way for a functional understanding of the HMA-LMA dichotomy in sponges.

\section{Acknowledgments}

We gratefully acknowledge the marine operations personnel at the National Undersea Research Center (Key Largo, Florida), the Ruder Boskovic Institute (Rovinj, Croatia), the Hellenic Center for Marine Research (HCMR, Crete, Greece), and the Coastal and Marine Resources Core Lab at KAUST (Thuwal, Saudi Arabia), in particular T. Ravasi and M. Berumen, for expert help during sponge collection. The crews of the R/V Seward Johnson II and F. G. Walton Smith (Harbor Branch Oceanographic Institute) are acknowledged for excellent support during field work. Financial support was provided by the DFG, SFB567TPC3 to U.H. LM-S was supported by a grant from the German Excellence Initiative to the Graduate School of Life Sciences, University of Wuerzburg.

\section{Literature Cited}

Akaike, H. 1974. A new look at the statistical model identification. IEEE Trans. Automat. Contr. 19: 716-723.

Bayer, K., S. Schmitt, and U. Hentschel. 2008. Physiology, phylogeny and in situ evidence for bacterial and archaeal nitrifiers in the marine sponge Aplysina aerophoba. Environ. Microbiol. 10: 2942-2955.

Bell, J. J. 2008. The functional roles of marine sponges. Estuar. Coast. Shelf Sci. 79: 341-353.

Bright, M., and S. Bulgheresi. 2010. A complex journey: transmission of microbial symbionts. Nat. Rev. Microbiol. 8: 218-230.

Chanas, B., and J. R. Pawlik. 1995. Defenses of Caribbean sponges against predatory reef fish II. Spicules, tissue toughness, and nutritional quality. Mar. Ecol. Prog. Ser. 127: 195-211.

Darriba, D., G. L. Taboada, R. Doallo, and D. Posada. 2012. jModelTest 2: more models, new heuristics and parallel computing. Nat. Methods 9: 772-772.

de Goeij, J. M., D. van Oevelen, M. J. Vermeij, R. Osinga, J. J. Middelburg, A. F. de Goeij, and W. Admiraal. 2013. Surviving in a marine desert: the sponge loop retains resources within coral reefs. Science 342: 108-110.

Dosse, G. 1939. Bakterien- und Pilzbefunde sowie pathologische und Fäulnis-Vorgänge im Meeres- sowie Sü $\beta$ wasserschwämmen. Untersuchungen mit dem gegenwärtigen Sterben der Badeschwämme in Westindien Z. Parasitenkd. 11: 331-356.

Ereskovsky, A. V., and D. B. Tokina. 2004. Morphology and fine structure of the swimming larvae of Ircinia oros (Porifera, Demospongiae, Dictyoceratida). Invertebr. Reprod. Dev. 45: 137-150.
Erpenbeck, D., O. Voigt, M. Gultas, and G. Worheide. 2008. The sponge genetree server-providing a phylogenetic backbone for poriferan evolutionary studies. Zootaxa 1939: 58-60.

Erwin, P. M., J. B. Olson, and R. W. Thacker. 2011. Phylogenetic diversity, host-specificity and community profiling of sponge-associated bacteria in the northern Gulf of Mexico. PLoS One 6:e26806.

Friedrich, A. B., H. Merkert, T. Fendert, J. Hacker, P. Proksch, and U. Hentschel. 1999. Microbial diversity in the marine sponge Aplysina cavernicola (formerly Verongia cavernicola) analyzed by fluorescence in situ hybridization (FISH). Mar. Biol. 134: 461-470.

Friedrich, A. B., J. Hacker, I. Fischer, P. Proksch, and U. Hentschel. 2001. Temporal variations of the microbial community associated with the Mediterranean sponge Aplysina aerophoba. FEMS Microbiol. Ecol. 38: 105-113.

Gerce, B., T. Schwartz, C. Syldatk, and R. Hausmann. 2011. Differences between bacterial communities associated with the surface or tissue of Mediterranean sponge species. Microb. Ecol. 61: 769-782.

Giles, E. C., J. Kamke, L. Moitinho-Silva, M. W. Taylor, U. Hentschel, T. Ravasi, and S. Schmitt. 2013. Bacterial community profiles in low microbial abundance sponges. FEMS Microbiol. Ecol. 83: 232241.

Gloeckner, V. 2013. Untersuchungen zur Diversität, Abundanz und vertikalen Weitergabe von Bakterien in marinen Schwämmen. Ph.D. thesis, University of Wuerzburg, Wuerzburg, Germany.

Gloeckner, V., U. Hentschel, A. V. Ereskovsky, and S. Schmitt. 2013a. Unique and species-specific microbial communities in Oscarella lobularis and other Mediterranean Oscarella species (Porifera: Homoscleromorpha). Mar. Biol. 160: 781-791.

Gloeckner, V., N. Lindquist, S. Schmitt, and U. Hentschel. 2013b. Ectyoplasia ferox, an experimentally tractable model for vertical microbial transmission in marine sponges. Microb. Ecol. 65: 462-474.

Hentschel, U., L. Fieseler, M. Wehrl, C. Gernert, M. Steinert, J. Hacker, and M. Horn. 2003. Microbial diversity of marine sponges. Prog. Mol. Subcell. Biol. 37: 59-88.

Hentschel, U., K. M. Usher, and M. W. Taylor. 2006. Marine sponges as microbial fermenters. FEMS Microbiol. Ecol. 55: 167-177.

Hentschel, U., J. Piel, S. M. Degnan, and M. W. Taylor. 2012. Genomic insights into the marine sponge microbiome. Nat. Rev. Microbiol. 10: 641-654.

Hochmuth, T., H. Niederkruger, C. Gernert, A. Siegl, S. Taudien, M. Platzer, P. Crews, U. Hentschel, and J. Piel. 2010. Linking chemical and microbial diversity in marine sponges: possible role for Poribacteria as producers of methyl-branched fatty acids. Chembiochem 11: $2572-2578$.

Kamke, J., M. W. Taylor, and S. Schmitt. 2010. Activity profiles for marine sponge-associated bacteria obtained by $16 \mathrm{~S}$ rRNA vs $16 \mathrm{~S}$ rRNA gene comparisons. ISME J. 4: 498-508.

Kamke, J., A. Sczyrba, N. Ivanova, P. Schwientek, C. Rinke, K. Mavromatis, T. Woyke, and U. Hentschel. 2013. Single-cell genomics reveals complex carbohydrate degradation patterns in poribacterial symbionts of marine sponges. ISME J. 7: 1-14.

Laroche, M., C. Imperatore, L. Grozdanov, V. Costantino, A. Mangoni, U. Hentschel, and E. Fattorusso. 2007. Cellular localisation of secondary metabolites isolated from the Caribbean sponge Plakortis simplex. Mar. Biol. 15: 1365-1373.

Levi, C., and A. Porte. 1962. Electron microscopy study of the sponge Oscarella lobularis and its amphiblastula larvae. Cah. Biol. Mar. 3: 307-315.

Li, C. W., J. Y. Chen, and T. E. Hua. 1998. Precambrian sponges with cellular structures. Science 279: 879-882.

Maldonado, M. 2007. Intergenerational transmission of symbiotic bacteria in oviparous and viviparous demosponges, with emphasis on intracytoplasmically-compartmented bacterial types. J. Mar. Biol. Assoc. UK 87: 1701-1713. 
Moitinho-Silva, L., K. Bayer, C. V. Cannistraci, E. C. Giles, T. Ryu, L. Seridi, T. Ravasi, and U. Hentschel. 2014. Specificity and transcriptional activity of microbiota associated with low and high microbial abundance sponges from the Red Sea. Mol. Ecol. 23: 1348-1363.

Montalvo, N. F., and R. T. Hill. 2011. Sponge-associated bacteria are strictly maintained in two closely related but geographically distant sponge hosts. Appl. Environ. Microbiol. 77: 7207-7216.

Pawlik, J. R., B. Chanas, R. J. Toonen, and W. Fenical. 1995. Defenses of Caribbean sponges against predatory reef fish I: chemical deterrency. Mar. Ecol. Prog. Ser. 127: 183-194.

Poppell, E., J. B. Weisz, L. Spicer, A. Massaro, A. Hill, and M. Hill. 2013. Sponge heterotrophic capacity and bacterial community structure in high- and low-microbial abundance sponges. Mar. Ecol. doi: 10.1111/maec. 12098

Redmond, N. E., C. C. Morrow, R. W. Thacker, M. C. Diaz, N. Boury-Esnault, P. Cardenas, E. Hajdu, G. Lobo-Hajdu, B. E. Picton, S. A. Pomponi, et al. 2013. Phylogeny and systematics of demospongiae in light of new small-subunit ribosomal DNA (18S) sequences. Integr. Comp. Biol. 53: 388-415.

Reiswig, H. M. 1974. Water transport, respiration and energetics of three tropical marine sponges J. Exp. Mar. Biol. Ecol. 14: 231-249.

Reiswig, H. M. 1981. Partial carbon and energy budgets of the bacteriosponge Verongia fistularis (Porifera: Demospongiae) in Barbados West-Indies. Mar. Biol. 2: 273-294.

Ribes, M., E. Jimenez, G. Yahel, P. Lopez-Sendino, B. Diez, R. Massana, J. H. Sharp, and R. Coma. 2012. Functional convergence of microbes associated with temperate marine sponges. Environ. Microbiol. 14: $1224-1239$.

Schiller, R. 2006. Untersuchungen zur Bakterienhaltigkeit in karibischen Schwämmen und ausgewählten Reproduktionsstadien, MS thesis, University of Wuerzburg, Wuerzburg, Germany.

Schlappy, M. L., S. I. Schottner, G. Lavik, M. M. Kuypers, D. de Beer, and F. Hoffmann. 2010. Evidence of nitrification and denitrification in high and low microbial abundance sponges. Mar. Biol. 157: 593602 .

Schmitt, S. 2007. Vertical microbial transmission in Caribbean bacteriosponges. Ph.D. thesis, University of Wuerzburg, Wuerzburg, Germany.

Schmitt, S., J. B. Weisz, N. Lindquist, and U. Hentschel. 2007. Vertical transmission of a phylogenetically complex microbial consortium in the viviparous sponge Ircinia felix. Appl. Environ. Microbiol. 73: 2067-2078.

Schmitt, S., H. Angermeier, R. Schiller, N. Lindquist, and U. Hentschel. 2008a. Molecular microbial diversity survey of sponge reproductive stages and mechanistic insights into vertical transmission of microbial symbionts. Appl. Environ. Microbiol. 74: 7694-7708.

Schmitt, S., M. Wehrl, L. Lindquist, J. B. Weisz, and U. Hentschel. 2008b. Morphological and molecular analyses of microorganisms in
Caribbean reef adult sponges and in corresponding reproductive material. Pp. 561-568 in Porifera Research Biodiversity, Innovation and Sustainability, M. R. Custódio, G. Lôbo-Hajdu, E. Hajdu, and G. Muricy, eds, Série Livros. 28. Museu Nacional, Rio de Janeiro.

Schmitt, S., P. Tsai, J. Bell, J. Fromont, M. Ilan, N. Lindquist, T. Perez, A. Rodrigo, P. J. Schupp, J. Vacelet, et al. 2012. Assessing the complex sponge microbiota: core, variable and species-specific bacterial communities in marine sponges. ISME J. 6: 564-576.

Simister, R. L., P. Deines, E. S. Botte, N. S. Webster, and M. W. Taylor. 2012. Sponge-specific clusters revisited: a comprehensive phylogeny of sponge-associated microorganisms. Environ. Microbiol. 14: $517-524$.

Stamatakis, A. 2006. RAxML-VI-HPC: maximum likelihood-based phylogenetic analyses with thousands of taxa and mixed models. Bioinformatics 22: 2688-2690.

Taylor, M. W., R. Radax, D. Steger, and M. Wagner. 2007. Spongeassociated microorganisms: evolution, ecology, and biotechnological potential. Microbiol. Mol. Biol. Rev. 71: 295-347.

Vacelet, J. 1975. Étude en microscopie electronique de l'association entre bacteries et spongiaires du genre Verongida (Dicytoceratida). $J$. Microsc. Biol. Cell. 23: 271-288.

Vacelet, J., and C. Donadey. 1977. Electron microscope study of the association between some sponges and bacteria. J. Exp. Mar. Biol. Ecol. 30: 301-314.

Van Soest, R. W., M. Boury-Esnault, N. Hooper, J. N. A. Rützler, K. de Voogd, N. J. Alvarez, B. de Glasby, E. Hajdu, A. B. Pisera, R. Manconi, et al. 2014. World Porifera database. [Online]. Available: http://www.marinespecies.org/porifera [2014, July 23].

Webster, N. S., R. I. Webb, M. J. Ridd, R. T. Hill, and A. P. Negri. 2001. The effects of copper on the microbial community of a coral reef sponge. Environ. Microbiol. 3: 19-31.

Webster, N. S., M. W. Taylor, F. Behnam, S. Lucker, T. Rattei, S. Whalan, M. Horn, and M. Wagner. 2010. Deep sequencing reveals exceptional diversity and modes of transmission for bacterial sponge symbionts. Environ. Microbiol. 12: 2070-2082.

Wehrl, M. 2006. Bakterielle Aufnahme, Selektivität und interne Prozessierung bei marinen Schwämmen (Porifera). Ph.D. thesis, University of Wuerzburg, Wuerzburg, Germany.

Weisz, J. B., U. Hentschel, N. Lindquist, and C. S. Martens. 2007. Linking abundance and diversity of sponge-associated microbial communities to metabolic differences in host sponges. Mar. Biol. 152: 475-483.

Weisz, J. B., N. Lindquist, and C. S. Martens. 2008. Do associated microbial abundances impact marine demosponge pumping rates and tissue densities? Oecologia 155: 367-376.

Wilkinson, C. R. 1978. Microbial associations in sponges. III. Ultrastructure of the in situ associations in coral reef sponges. Mar. Biol. 49: $177-185$. 